Pol. J. Food Nutr. Sci., 2019, Vol. 69, No. 1, pp. 101-108 DOI: $10.31883 /$ pjfns-2019-0010 http://journal.pan.olsztyn.pl

Original research article

Section: Food Technology

\title{
Intermittent Microwave-Vacuum Drying Effects on Pears
}

\author{
Onur Taskin ${ }^{1}$, Ahmet Polat ${ }^{1}$, Nazmi Izli $^{1 *}$, Baris Bulent Asik ${ }^{2}$ \\ ${ }^{1}$ Department of Biosystems Engineering, Faculty of Agriculture, Bursa Uludag University, \\ Gorukle Campus, 16059, Bursa, Turkey \\ ${ }^{2}$ Department of Soil Science and Plant Nutrition, Faculty of Agriculture, \\ Bursa Uludag University, Gorukle Campus, 16059, Bursa, Turkey
}

Key words: microwave-vacuum drying, mineral content, protein, rehydration ratio, color, scanning electron microscopy

\begin{abstract}
In the present study, the effects of intermittent microwave-vacuum drying on the "Deveci" pear in terms of the drying kinetics, mineral content, protein content, rehydration ratio, color, energy, specific energy and microstructure were investigated. According to the drying treatments, increased microwave power (100 and $200 \mathrm{~W})$ and vacuum $(200$ and $400 \mathrm{mmHg}$ ) applications provided higher drying rates and protein content. Dried pear samples had a higher mineral content than fresh samples because of the increasing dry matter content. At the higher vacuum level experiments, the energy consumption reduced and the rehydration ratio increased. Moreover, the higher microwave power caused a decrease of the $L^{*}$ (lightness) value. However, a regular pore size and pore distribution in all drying experiments were observed in the microstructures of microwave-vacuum-dried samples.
\end{abstract}

\section{INTRODUCTION}

The pear (Pyrus communis L.) belongs to the Rosaceae family [Antal et al., 2017]. It is a fruit native to temperate zones and is cultivated in Europe [Guiné et al., 2007]. According to the Food and Agriculture Organization data [FAO, 2018], the worldwide pear production in 2014 was estimated at approximately 25.8 million tons. Fully mature pears play an important role in the human diet and nutrition as sources of dietary fiber, vitamins $\mathrm{C}_{\text {and }} \mathrm{B}_{6}$, and minerals such as magnesium and potassium [Lutovska et al., 2016]. They are eaten in both the natural and processed forms as purees, jams, and dried pears [Santos, et al., 2014]. In fact, dried pears are widely used in bakery products, gravies, and compotes [Doymaz \& İsmail, 2012].

Drying is a complex biological and chemical reaction whose mechanism is not yet entirely understood [Ferreira et al., 2008]. However, it is widespread industrial preservation method used to decrease water content of agricultural products to minimize chemical, biochemical, and microbiological deterioration [Doymaz \& İsmail, 2012], as well as to prolong the shelf life of the fruit, and avoid spoilage and contamination during storage. Using an appropriate drying procedure also minimizes storage and transportation costs [Doymaz, 2013]. Therefore, drying methods have been garnering increased attention, and detailed studies have been conducted on the effects of different [Lüle \& Koyuncu, 2015] or hybrid

\footnotetext{
* Corresponding Author: Tel.: +90 224294 16 04; Fax: +90 22429414 02;

E-mail nazmiizli@gmail.com (N. Izli)
}

drying [Huang et al., 2015] methods on food quality. In recent years, drying with a microwave vacuum has been used as a hybrid method for top-quality dried products [Cui et al., 2003]. The advantage of the microwave-vacuum process is drying acceleration under low temperature by an increased pressure gradient between layers [Therdthai \& Zhou, 2009]. If the microwave being used is not applied properly, poor-quality products may be manufactured due to irregular drying depending on product characteristics, shape, and size [Han et al., 2010; Kuş, 2016]. Thus far, intermittent microwave application during drying has been an effective methodology to avoid improper heating and improve product quality and energy efficiency within the product during microwave off times [Zhang et al., 2017].

There are ample literature data on the drying of pears using various drying methods, such as osmotic pre-treated convective air drying [González-Martínez et al., 2006], solar drying [Guiné et al., 2007], sun drying [Ferreira et al., 2008], hot air drying [Doymaz \& İsmail, 2012], ultrasound-assisted infrared drying [Dujmić et al., 2013], solar stove of greenhouse type drying [Guiné et al., 2013], convective drying [Lutovska et al., 2016; Santos et al., 2014], osmo-vacuum drying [Amiripour et al., 2015], forced air convection drying [Dotto et al., 2017], microwave drying [Kuş, 2016], intermittent convective drying [Silva et al., 2014], and infrared and freeze drying [Antal et al., 2017]. To the best of our knowledge, no study has been reported on the intermittent microwave-vacuum drying effect on pear slices. The pear cultivar "Deveci" is one of the best winter-type pear cultivars in Turkey, originating from Anatolia, that has recently gained popularity because 
of the high fruit quality, production and storage capacity [Ozturk \& Ozturk, 2014]. Therefore, this study was aimed to investigate the drying kinetics of "Deveci" pear slices and drying effects on the mineral content, protein content, rehydration ratio, color, energy specific energy and microstructure analyses when using intermittent microwave-vacuum drying conditions.

\section{MATERIALS AND METHODS}

\section{Drying experiments}

Wholly matured and healthy fruits of "Deveci" pears were selected for this study and were stored before drying at $4 \pm 0.5^{\circ} \mathrm{C}$ for a day. The initial moisture content of fresh samples was determined by oven drying (ED115; Binder, Tuttlingen, Germany) at $105^{\circ} \mathrm{C}$ [Celen \& Kahveci, 2013] and was found to be 5.67 (g water/g dry matter). The samples were dried until the final moisture content of 0.1 (g water/g dry matter). The samples were horizontal sliced into $5 \pm 0.04-\mathrm{mm}$ thickness using a food slicer (Nicer Dicer, China).

The drying experiments were carried out in a custom-modified intermittent microwave-vacuum dryer with a power output of $900 \mathrm{~W}$ and a microwave frequency of $2450 \mathrm{MHz}$. It consists of a microwave oven (NE1846; Panasonic, Japan), vacuum pump (VRT404; Bacca, Taiwan), voltage variac (DVT2.5; Devotrans, Turkey), pulse controller (MCB9; Entes, Turkey), and glass container (Figure 1). Before starting the drying experiments, the glass container with the dimensions of 200 (diameter) $\times 92$ (height) $\mathrm{mm}$ with the pear to be dried was positioned inside the microwave cavity, and the pressure inside the container was managed by a pressure regulator valve connected to a $0.18-\mathrm{kW}$ vacuum pump and was monitored using a vacuum gauge. Once the vacuum level was reached, the microwave oven was run, and various output power levels and the pulse ratio were adjusted using a voltage variac and pulse controller, respectively [Kumar \& Shrivastava, 2017; Zaki et al., 2007]. The weight of the sample $(80 \mathrm{~g})$ was determined by the digital balance (Radwag, Radom, Poland) and was recorded at 10-min intervals after turning off the microwave-vacuum dryer [Zaki et al., 2007]. The experimental conditions of drying included: microwave power of 100 and $200 \mathrm{~W}$, vacuum pressure of 200 and $400 \mathrm{mmHg}$, and pulse ratio of 3 and 4 . The pulse ratio (PR) for each run was computed as $P R=\left(t_{\text {on }}+t_{\text {off }}\right) / t_{\text {on }}$, where $\mathrm{t}_{\text {on }}$ is the magnetron power "on" time and $\mathrm{t}_{\text {off }}$ is the mag-

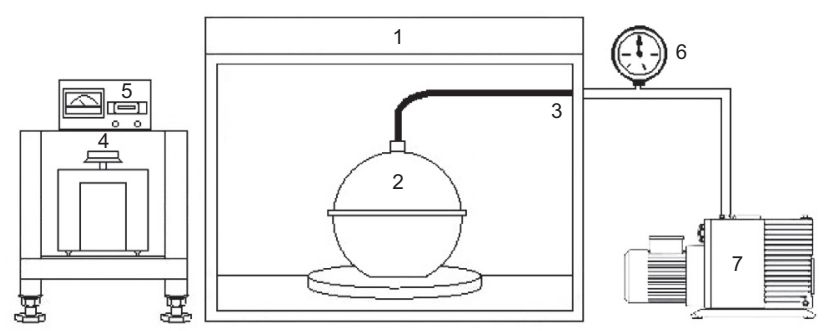

FIGURE 1. Schematic diagram of the laboratory apparatus: (1) dryer, (2) glass container, (3) teflon hose, (4) variac, (5) pulse controller, (6) vacuum gauge, and (7) vacuum pump. netron power "off" time [Gunasekaran \& Yang, 2007]. During the study, $20 \mathrm{~s}$ of $\mathrm{t}_{\text {on }}$ and $40 \mathrm{~s}$ of $\mathrm{t}_{\text {off }}$ represented $\mathrm{PR}=3$, and $15 \mathrm{~s}$ of $\mathrm{t}_{\text {on }}$ and $45 \mathrm{~s}$ of $\mathrm{t}_{\text {off }}$ represented $\mathrm{PR}=4$.

\section{Determining mineral contents}

The total contents of some elements were determined by using dry samples after microwave treatment of the 0.20 0.50 g samples with $4 \mathrm{~mL} \mathrm{HNO}_{3}$ and $3 \mathrm{~mL} \mathrm{H}_{2} \mathrm{O}_{2}$ in a microwave oven (MWS 2 DAP 60K, Berghof, Germany). Contents of $\mathrm{Na}, \mathrm{K}$, and $\mathrm{Ca}$ were determined by the flame emission method using a flame photometer (6361, Eppendorf Elex, Germany), whereas these of $\mathrm{P}, \mathrm{Mg}, \mathrm{Fe}, \mathrm{Cu}, \mathrm{Zn}$, and $\mathrm{Mn}$ was determined in the extracts using inductively coupled plasma optical emission spectroscopy (ICP OES) and expressed in $\mathrm{mg} / \mathrm{kg}$ (Optima 2100 DV, Perkin Elmer, United States).

\section{Determining protein contents}

The Kjeldahl method was used to determine the protein content in pear samples. The conventional factor 6.25 was used to obtain the protein content of fruits [AOAC, 1960]. Digestion/distillation unit (K-437/K-350, Buchi, Switzerland) was used for nitrogen determination.

\section{Rehydration ratio}

Dried pear samples were rehydrated by immersion in a distilled water bath at a controlled temperature of $25^{\circ} \mathrm{C}$. The weight of dehydrated pear samples used in each experiment was $5 \pm 0.02 \mathrm{~g}$. Rehydration of dried pears was stopped after three hours. Next, the samples were drained with a tissue paper to remove excess water from the surface. The data were quantified in terms of the rehydration ratio (RR) using the following formula [Zielinska et al., 2016]:

$$
\mathrm{RR}=\frac{\text { Mass of the rehydrated sample }}{\text { Mass of the dried sample }}
$$

\section{Color measurements}

The color of the pear sample was measured before and after drying using a colorimeter (Hunter Lab, MSEZ-4500L, USA) at four different points on the pear's sample for all experiments. The color values were indicated as $L^{*}$ (whiteness/darkness), $a^{*}$ (redness/greenness), and $b^{*}$ (yellowness/ blueness). Additionally, $L_{0}{ }^{*}, a_{0}{ }^{*}$ and $b_{0}{ }^{*}$ represented the color parameters of the fresh samples. The following formulas were used to calculate Chroma $C$ (Eq. 2), hue angle $\alpha$ (Eq. 3), and total color difference $\Delta E$ (Eq. 4), [İzli, 2017]:

$$
\begin{aligned}
C & =\sqrt{\left(a^{2}+b^{2}\right)} \\
\alpha & =\tan ^{-1}\left(\frac{b}{a}\right) \\
\Delta E & =\sqrt{\left(L_{0}^{*}-L^{*}\right)^{2}+\left(a_{0}^{*}-a^{*}\right)^{2}+\left(b_{0}^{*}-b^{*}\right)^{2}}
\end{aligned}
$$

\section{Energy and specific energy consumption}

The energy consumption values of the intermittent microwave-vacuum drying processes were measured using a power meter (EU TS-836A; Floureon, China). The drying devices 
(i.e., the microwave oven and vacuum pump) were connected to the power meter that was on the electric grid. During the drying conditions, the energy consumption values were recorded by the power meter in kWh [Orikasa et al., 2018]. The energy required to evaporate a unit mass of water from the sample (specific energy consumption, SEC) was calculated for each drying experiment. It was defined in terms of the $\mathrm{MJ} / \mathrm{kg}$ of water removed and was used as process parameters of optimization [Kumar \& Shrivastava, 2017].

$$
\operatorname{SEC}(M J / k g)=\frac{t_{o n} M\left(1-m_{f}\right) \times 10^{-6}}{M_{i}\left(m_{i}-m_{f}\right)}
$$

where: $t_{\text {on }}$ is the total power on time (s), $M$ is microwave input power $(\mathrm{W}), M_{i}$ is the initial mass of the sample $(\mathrm{kg}), m_{i}$ is the initial moisture content (g water/g dry matter), and $m_{f}$ is the final moisture content (g water/g dry matter).

\section{Microstructure analysis}

The effect of different drying conditions on the microstructure of pear samples was observed using a scanning electron microscope (EVO 40, Carl Zeiss, Oberkochen, Germany). Particles extracted from the dried samples were vertically cut into 1-mm-thick slices and coated with gold-palladium. All samples were examined under high vacuum $(20 \mathrm{kV})$ (SCD005, Baltec, Wetzlar, Germany), and then their microphotographs were taken [Tian et al., 2015].

\section{Statistical analysis}

The study was performed using randomized plots factorial design of experimental type. All experiments were done in triplicate. The data were subjected to the analysis of variance (ANOVA) using JMP software (Version 7.0; SAS Institute Inc., Cary, NC, USA). The least significant difference (LSD) test was used to compare the means at the 5\% significance level $(\mathrm{P}<0.05)$.

\section{RESULTS AND DISCUSSION}

\section{Drying kinetics}

The drying rates of the "Deveci" pear dried by the intermittent microwave-vacuum methodology are shown in Figure 2. A higher microwave power and vacuum application provided higher drying rates. The shortest drying time of pears $(150 \mathrm{~min})$ was noted at process conditions "200 W $-400 \mathrm{mmHg}-\mathrm{PR}=3$ ", and the longest one (460 min) at " $100 \mathrm{~W}-200 \mathrm{mmHg}-\mathrm{PR}=4$ ". These results indicate that it was possible to decrease the drying time by $310 \mathrm{~min}$. A higher microwave power with more microwave energy made the pears have a higher temperature and increased the evaporation rate. With a rapid increase in the mass transfer rate of the pear, the drying time was reduced. The drying rates of the pear dried by constant microwave power and a pulse ratio under a vacuum of $400 \mathrm{mmHg}$ were higher than those dried under $200 \mathrm{mmHg}$ because a higher vacuum resulted in a lower boiling point of water and a higher evaporation rate. Several authors reported the total times for the drying of the pear to be $525,480,360$ and $255 \mathrm{~min}$ in a convective dryer at 50, 57, 64 and $71^{\circ} \mathrm{C}$, respectively [Doymaz, 2013]; as well as 20, 19, 16, 14 and $1260 \mathrm{~min}$ in an infrared dryer at $40,50,60,70^{\circ} \mathrm{C}$ and in a freeze dryer $\left(-47^{\circ} \mathrm{C}\right.$ condenser temperature and 85-95 $\mathrm{Pa}$ absolute pressure), respectively [Antal et al., 2017]. On the other hand, the results were in good agreement with those reported by Cheenkachorn et al. [2012] who used a microwave-vacuum method to dry papaya cubes. Their drying times at a vacuum pressure of $400 \mathrm{mmHg}$, were 72.6, 115.5, 38.2, and $84 \mathrm{~min}$ at " $400 \mathrm{~W}-\mathrm{PR}=2$ ", "400 W $\mathrm{PR}=3 ", " 800 \mathrm{~W}-\mathrm{PR}=2$ ", and " $800 \mathrm{~W}-\mathrm{PR}=3$ ", respectively. Additionally, the drying time decreased with vacuum pressure increase.

\section{Mineral content}

The mineral contents of intermittent microwave-vacuum dried "Deveci" pears are shown in Table 1. The "Deveci" pears were found a significant source of $\mathrm{K}$, whereas their $\mathrm{Mn}$ contents were low. The mineral contents of pears exposed to different drying treatments were higher than those of fresh fruits because of the increased dry matter ratio. The highest $\mathrm{K}$ levels determined at " $100 \mathrm{~W}-200 \mathrm{mmHg}-\mathrm{PR}=4$ ", "100 W $400 \mathrm{mmHg}-\mathrm{PR}=3$ ", and " $200 \mathrm{~W}-400 \mathrm{mmHg}-\mathrm{PR}=4$ " did not differ significantly $(\mathrm{P}>0.05)$. On the other hand, the high-
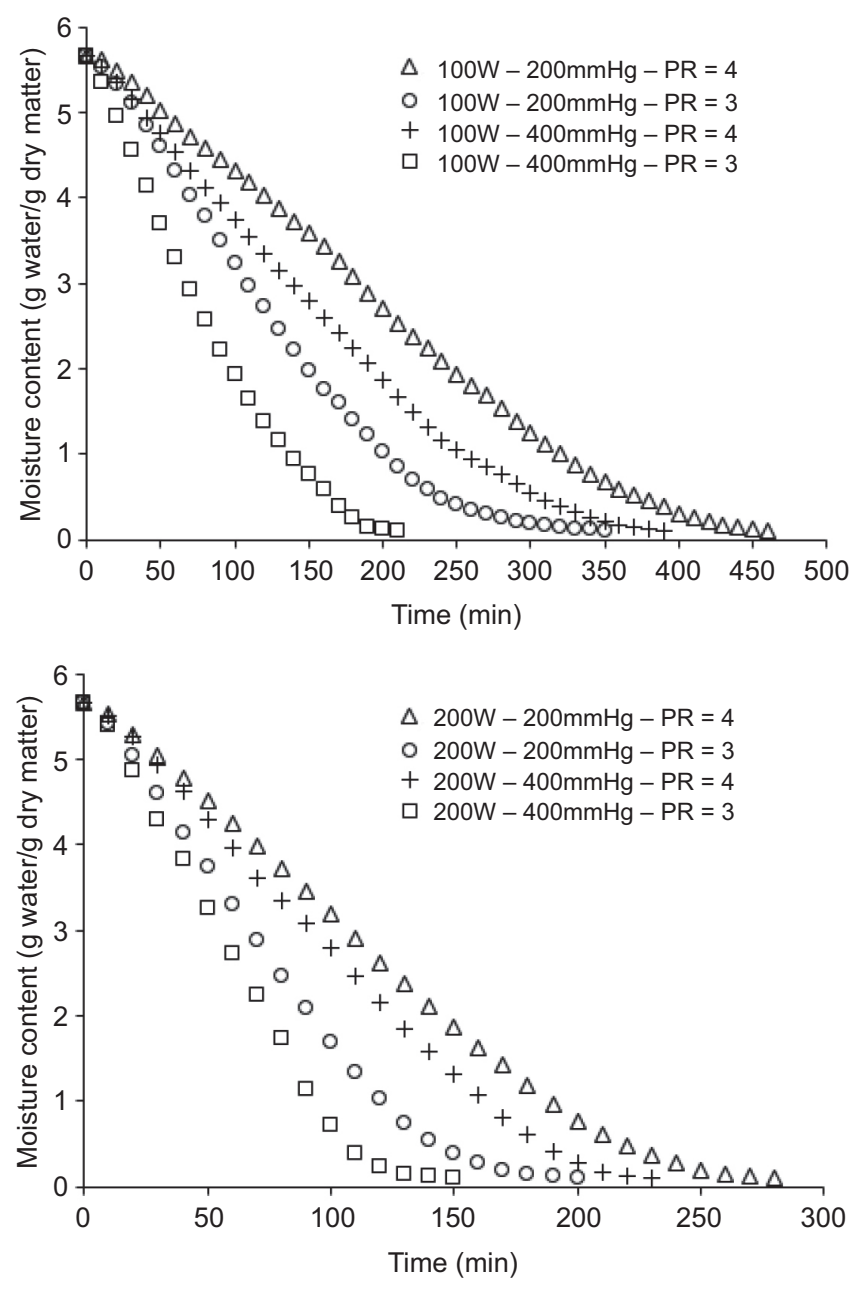

FIGURE 2. The moisture content of the "Deveci" pear vs. time under different drying conditions of pulses ( $P R=3$ and 4$)$, microwave powers (100 and $200 \mathrm{~W}$ ), and vacuum levels (200 and $400 \mathrm{mmHg}$ ). 
TABLE 1. Mineral contents of "Deveci" pears $(\mathrm{mg} / \mathrm{kg})$ fresh and dried under different conditions of pulses ( $\mathrm{PR}=3$ and 4$)$, microwave powers (100 and $200 \mathrm{~W}$ ), and vacuum levels (200 and $400 \mathrm{mmHg}$ ).

\begin{tabular}{l|c|c|c|c|c|c|c|c|c}
\hline Minerals & Fresh & $\begin{array}{c}100 \mathrm{~W} \\
200 \mathrm{mmHg} \\
\mathrm{PR}=4\end{array}$ & $\begin{array}{c}100 \mathrm{~W} \\
200 \mathrm{mmHg} \\
\mathrm{PR}=3\end{array}$ & $\begin{array}{c}100 \mathrm{~W} \\
400 \mathrm{mmHg} \\
\mathrm{PR}=4\end{array}$ & $\begin{array}{c}100 \mathrm{~W} \\
400 \mathrm{mmHg} \\
\mathrm{PR}=3\end{array}$ & $\begin{array}{c}200 \mathrm{~W} \\
200 \mathrm{mmHg} \\
\mathrm{PR}=4\end{array}$ & $\begin{array}{c}200 \mathrm{~W} \\
200 \mathrm{mmg} \\
\mathrm{PR}=3\end{array}$ & $\begin{array}{c}200 \mathrm{~W} \\
400 \mathrm{mmHg} \\
\mathrm{PR}=4\end{array}$ & $\begin{array}{c}200 \mathrm{~W} \\
400 \mathrm{mmHg} \\
\mathrm{PR}=3\end{array}$ \\
\hline $\mathrm{P}$ & $464 \pm 6^{\mathrm{d}}$ & $1446 \pm 27^{\mathrm{a}}$ & $1049 \pm 144^{\mathrm{bc}}$ & $1206 \pm 33^{\mathrm{abc}}$ & $1300 \pm 92^{\mathrm{ab}}$ & $1206 \pm 291^{\mathrm{abc}}$ & $1159 \pm 76^{\mathrm{bc}}$ & $979 \pm 26^{\mathrm{c}}$ & $1238 \pm 6^{\mathrm{abc}}$ \\
$\mathrm{K}$ & $353 \pm 136^{\mathrm{e}}$ & $6470 \pm 114^{\mathrm{ab}}$ & $3521 \pm 62^{\mathrm{d}}$ & $3424 \pm 167^{\mathrm{d}}$ & $7533 \pm 1107^{\mathrm{a}}$ & $3445 \pm 588^{\mathrm{d}}$ & $4383 \pm 472^{\mathrm{cd}}$ & $6987 \pm 551^{\mathrm{a}}$ & $5523 \pm 13^{\mathrm{bc}}$ \\
$\mathrm{Ca}$ & $64.8 \pm 0.8^{\mathrm{f}}$ & $291 \pm 25^{\mathrm{cd}}$ & $258 \pm 40^{\mathrm{de}}$ & $364 \pm 25^{\mathrm{ab}}$ & $292 \pm 34^{\mathrm{cd}}$ & $279 \pm 14^{\mathrm{de}}$ & $224 \pm 34^{\mathrm{e}}$ & $423 \pm 7^{\mathrm{a}}$ & $343 \pm 25^{\mathrm{bc}}$ \\
$\mathrm{Mg}$ & $47.1 \pm 1.5^{\mathrm{d}}$ & $284 \pm 11^{\mathrm{b}}$ & $228 \pm 4^{\mathrm{c}}$ & $290 \pm 16^{\mathrm{b}}$ & $378 \pm 20^{\mathrm{a}}$ & $223 \pm 16^{\mathrm{c}}$ & $235 \pm 6^{\mathrm{c}}$ & $376 \pm 48^{\mathrm{a}}$ & $338 \pm 4^{\mathrm{a}}$ \\
$\mathrm{Na}$ & $246 \pm 2^{\mathrm{e}}$ & $733 \pm 56^{\mathrm{a}}$ & $536 \pm 52^{\mathrm{d}}$ & $629 \pm 5^{\mathrm{bc}}$ & $640 \pm 30^{\mathrm{ab}}$ & $621 \pm 73^{\mathrm{bcd}}$ & $629 \pm 17^{\mathrm{bc}}$ & $579 \pm 49^{\mathrm{cd}}$ & $685 \pm 0.4^{\mathrm{ab}}$ \\
$\mathrm{Fe}$ & $3.97 \pm 1.00^{\mathrm{c}}$ & $8.84 \pm 0.88^{\mathrm{ab}}$ & $6.71 \pm 1.30^{\mathrm{bc}}$ & $8.19 \pm 0.54^{\mathrm{ab}}$ & $10.96 \pm 2.37^{\mathrm{a}}$ & $6.82 \pm 2.26^{\mathrm{bc}}$ & $6.58 \pm 034^{\mathrm{bc}}$ & $8.71 \pm 1.43^{\mathrm{ab}}$ & $8.41 \pm 0.75^{\mathrm{ab}}$ \\
$\mathrm{Cu}$ & $2.89 \pm 0.03^{\mathrm{d}}$ & $7.29 \pm 0.24^{\mathrm{b}}$ & $5.53 \pm 0.92^{\mathrm{c}}$ & $7.39 \pm 0.44^{\mathrm{b}}$ & $8.87 \pm 0.52^{\mathrm{a}}$ & $7.46 \pm 1.36^{\mathrm{ab}}$ & $6.98 \pm 0.37^{\mathrm{bc}}$ & $6.82 \pm 0.55^{\mathrm{bc}}$ & $7.69 \pm 0.41^{\mathrm{ab}}$ \\
$\mathrm{Zn}$ & $2.35 \pm 0.07^{\mathrm{c}}$ & $5.20 \pm 0.01^{\mathrm{ab}}$ & $3.93 \pm 0.51^{\mathrm{b}}$ & $4.82 \pm 0.22^{\mathrm{ab}}$ & $5.58 \pm 0.08^{\mathrm{a}}$ & $5.38 \pm 1.21^{\mathrm{a}}$ & $4.03 \pm 0.73^{\mathrm{b}}$ & $5.14 \pm 0.75^{\mathrm{ab}}$ & $5.12 \pm 0.43^{\mathrm{ab}}$ \\
$\mathrm{Mn}$ & $0.56 \pm 0.02^{\mathrm{f}}$ & $0.94 \pm 0.04^{4^{\mathrm{ef}}}$ & $1.34 \pm 0.01^{\mathrm{de}}$ & $3.47 \pm 0.01^{\mathrm{a}}$ & $2.06 \pm 0.12^{\mathrm{c}}$ & $1.83 \pm 0.13^{\mathrm{c}}$ & $1.66 \pm 0.01^{\mathrm{cd}}$ & $2.74 \pm 0.55^{\mathrm{b}}$ & $1.89 \pm 0.01^{\mathrm{c}}$ \\
\hline
\end{tabular}

a-g means with different letters in the same row differ significantly $(\mathrm{P}<0.05)$.

est Mn level was found at "100 W - $400 \mathrm{mmHg}-\mathrm{PR}=4$ ". There were significant differences between drying experiments in terms of contents of all minerals compared with the fresh samples $(\mathrm{P}<0.05)$. Al Juhaimi et al. [2016] reported the mineral contents of three pear varieties ("Santa Maria", "Deveci" and "Ankara"). The P, K, Ca, Mg, Fe, and Mn contents of fresh "Deveci" pears were found to be 164.3, 1255.4, 42, $101.5,19.7$, and $1.5 \mathrm{mg} / \mathrm{kg}$, respectively. On the other hand, contents of $\mathrm{Na}, \mathrm{Cu}$, and $\mathrm{Zn}$ were closer to those of the presented study. The differences between the studies can be attributed to the growth conditions of "Deveci" pears which were picked in the province of Bursa and Konya. After drying 5 -mm slices of "Deveci" pears for 15,20 , and $25 \mathrm{~h}$ at $70^{\circ} \mathrm{C}$, the $\mathrm{K}$ content increased to $5298,7245.6$, and $7649.1 \mathrm{mg} / \mathrm{kg}$, respectively, similar to that in our presented study. In another previous study performed by Clary et al. [2007], grapes dried at $71{ }^{\circ} \mathrm{C}$ using microwave-vacuum dehydration had higher contents of $\mathrm{Ca}$, $\mathrm{Na}$, and $\mathrm{K}$ than sundried and fresh grapes. However, lower values were reported for Fe in that study.

\section{Protein analysis}

Figure 3 demonstrates that the protein content of the dried "Deveci" pears was higher than that of the fresh fruit because of the decreased water content. Compared with the protein content, an increase in common or individual microwave power and vacuum level provided higher protein values. Between drying treatments, the values obtained at " $200 \mathrm{~W}$ $400 \mathrm{mmHg}-\mathrm{PR}=3$ " and " $100 \mathrm{~W}-400 \mathrm{mmHg}-\mathrm{PR}=3$ " did

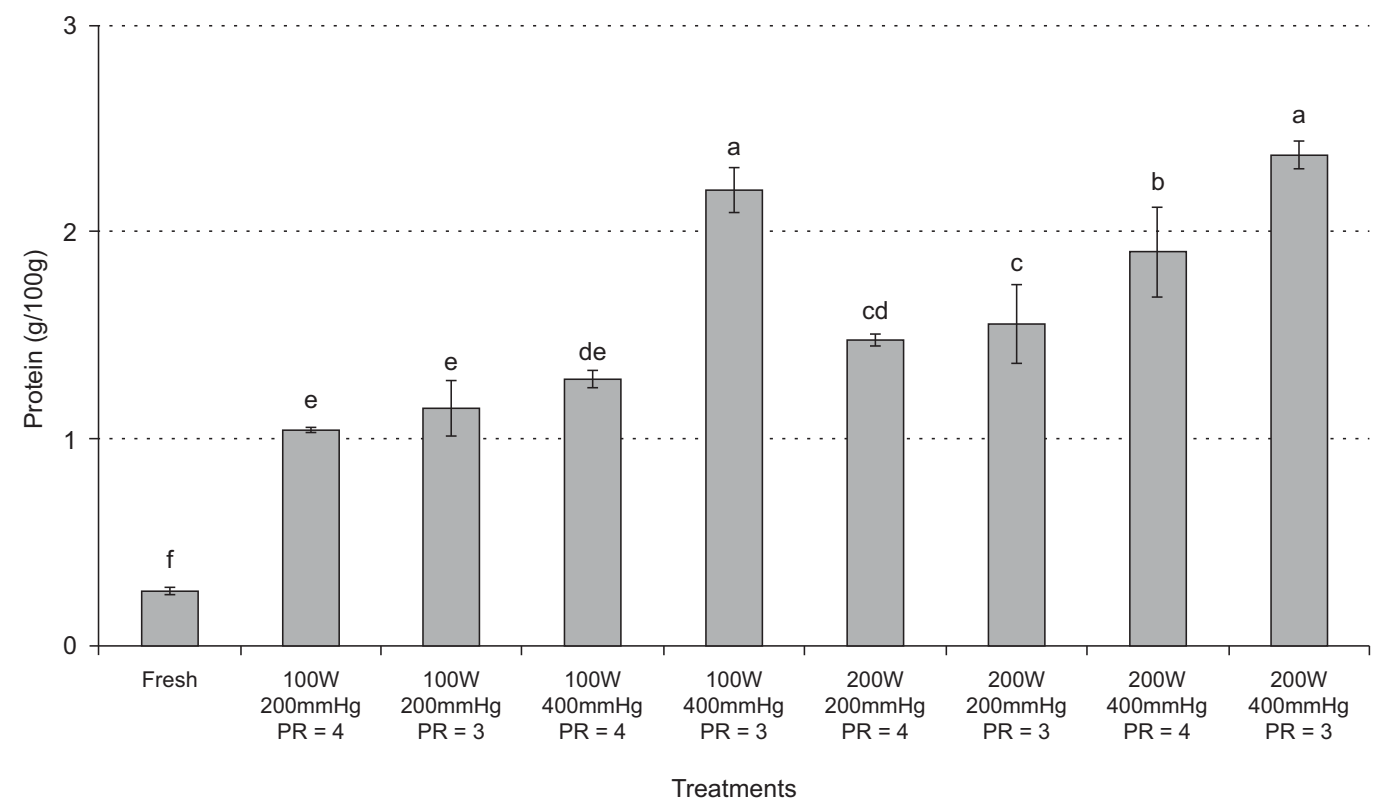

FIGURE 3. Protein content of "Deveci" pears fresh and dried under different conditions of pulses ( $P R=3$ and 4), microwave powers (100 and $200 \mathrm{~W}$ ), and vacuum levels (200 and $400 \mathrm{mmHg}$ ). 


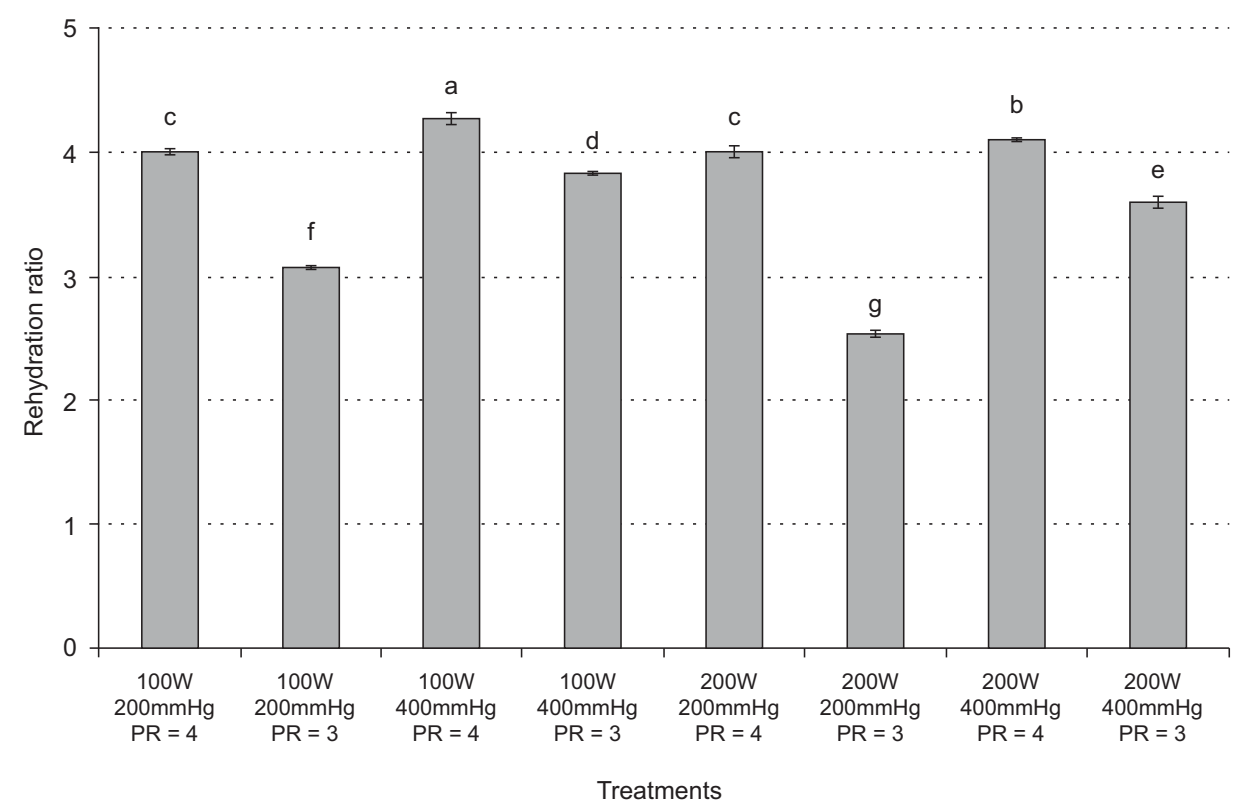

FIGURE 4. Rehydration ratio of "Deveci" pears dried under different conditions of pulses ( $P R=3$ and 4), microwave powers (100 and $200 \mathrm{~W}$ ), and vacuum levels (200 and $400 \mathrm{mmHg}$ ).

not differ significantly $(\mathrm{P}>0.05)$ and these process conditions resulted in the highest protein content of pears, whereas treatments at " $100 \mathrm{~W}-200 \mathrm{mmHg}-\mathrm{PR}=4$ " and " $100 \mathrm{~W}$ $200 \mathrm{mmHg}-\mathrm{PR}=3$ " caused the lowest protein content with comparable values $(\mathrm{P}>0.05)$. The possible reason for such a result might be the longer drying time. In an earlier study, protein content of fresh "Deveci" pear cultivar was found to be $3.8 \mathrm{~g} / \mathrm{L}$ as reported by Öztürk et al. [2009], and an intermittent microwave-vacuum effect on the protein results was reported by Dermelj et al. [1995] and although impulse technique was gentler, a virtual increase was not observed in the protein content.

\section{Rehydration ratio}

The change in the rehydration ratio with change in the microwave power, pulse ratio, and vacuum level is shown in Figure 4 . The rehydration ratio was found to be different between the drying treatments, and a higher rehydration ratio was observed at " $100 \mathrm{~W}-400 \mathrm{mmHg}-\mathrm{PR}=4$ ". The higher pulse ratio $(\mathrm{PR}=4)$ increased the rehydration ratio values, but the microwave power modes did not show any meaningful influence. However, the increased vacuum level experiments presented a higher rehydration ratio. Similarly, Changrue et al. [2008] found for strawberry drying with a microwave-vacuum method that the generated power modes were inadequate to affect the rehydration property. According to Jiang et al. [2014], the pulse-spouted microwave vacuum-dried banana cubes had a lower final rehydration ratio (3.6) than freeze (3.9) and microwave freeze dried samples (3.7).

\section{Color analysis}

The color parameters of the fresh "Deveci" pears and these dried by intermittent microwave-vacuum are presented in Table 2. All drying experiments provided higher values of redness $\left(a^{*}\right)$ and yellowness $\left(b^{*}\right)$ but lower lightness $\left(L^{*}\right)$. Drying conditions significantly $(\mathrm{P}<0.05)$ affected color values of "Deveci" pear samples. Using higher microwave power at a constant pulse ratio and vacuum level caused lower values of $L^{*}$. Furthermore, the maximum $a^{*}$ value for the dried samples was $a^{*}=17.3(\mathrm{P}<0.05)$ in the drying experiment at "200 W - $200 \mathrm{mmHg}-\mathrm{PR}=3$ ". Meanwhile, the significantly $(\mathrm{P}<0.05)$ higher $b^{*}$ and $C$ values were achieved at " $100 \mathrm{~W}$ $200 \mathrm{mmHg}-\mathrm{PR}=3$ ". Compared with the fresh sample, a significant $(\mathrm{P}<0.05)$ decrease was determined in the $\alpha$ value in all experiments. In the present study, the flesh color of the fresh "Deveci" pears was found to be higher in $L^{*}$ and $a^{*}$ values but lower in $b^{*}, C$ and $\alpha$ values than those previously reported by Ulubaş Serçe et al. [2010] using the same method. A similar effect of the microwave-vacuum drying method on the $L^{*}$ value was found by Bai-Ngew et al. [2015].

\section{Energy and specific energy analyses}

Table 3 shows the effects of the microwave power, pulse ratio, and vacuum level on the energy and specific energy consumption values of the dried "Deveci" pear. The lowest energy consumption value was at "200 W $400 \mathrm{mmHg}-\mathrm{PR}=3$ ”, likely due to the shortest drying time, despite the large power and pulse ratio input of the devices used in these processes. The energy consumption values of the " $100 \mathrm{~W}-400 \mathrm{mmHg}-\mathrm{PR}=3$ " and " $200 \mathrm{~W}$ $400 \mathrm{mmHg}-\mathrm{PR}=4$ " experiments were found to be approximately 1.4 and 1.5 times higher. The effect of the vacuum level clearly demonstrated that a strong relationship exists to reduce the energy consumption. For the same reason, the energy consumption values in the constant microwave power and pulse ratio experiments at a higher vacuum level were lower. Considering the specific energy consumption of "Deveci" pear drying, a higher vacuum level with a constant microwave power and pulse ratio resulted in a decreased consumption. The specific energy consumption, however, was increased by raising the microwave power from $100 \mathrm{~W}$ to $200 \mathrm{~W}$. Because of the shorter drying times, 
TABLE 3. Energy and specific energy consumption values of "Deveci" pears dried under different conditions of pulses $(\mathrm{PR}=3$ and 4$)$, microwave powers (100 and $200 \mathrm{~W}$ ), and vacuum levels (200 and $400 \mathrm{mmHg}$ ).

\begin{tabular}{|c|c|c|c|}
\hline $\begin{array}{l}\text { Drying } \\
\text { methods }\end{array}$ & $\begin{array}{c}\text { Drying } \\
\text { time } \\
(\mathrm{min})\end{array}$ & $\begin{array}{c}\text { Energy } \\
\text { consumption } \\
(\mathrm{kWh})\end{array}$ & $\begin{array}{c}\text { Specific energy } \\
\text { consumption } \\
(\mathrm{MJ} / \mathrm{kg})\end{array}$ \\
\hline $\begin{array}{l}100 \mathrm{~W} \\
200 \mathrm{mmHg} \\
\mathrm{PR}=4\end{array}$ & 460 & 2.6 & 1.6 \\
\hline $\begin{array}{l}100 \mathrm{~W} \\
200 \mathrm{mmHg} \\
\mathrm{PR}=3\end{array}$ & 350 & 2.3 & 1.6 \\
\hline $\begin{array}{l}100 \mathrm{~W} \\
400 \mathrm{mmHg} \\
\mathrm{PR}=4\end{array}$ & 390 & 2.2 & 1.4 \\
\hline $\begin{array}{l}100 \mathrm{~W} \\
400 \mathrm{mmHg} \\
\mathrm{PR}=3\end{array}$ & 210 & 1.3 & 1.0 \\
\hline $\begin{array}{l}200 \mathrm{~W} \\
200 \mathrm{mmHg} \\
\mathrm{PR}=4\end{array}$ & 280 & 1.6 & 1.9 \\
\hline $\begin{array}{l}200 \mathrm{~W} \\
200 \mathrm{mmHg} \\
\mathrm{PR}=3\end{array}$ & 200 & 1.3 & 1.9 \\
\hline $\begin{array}{l}200 \mathrm{~W} \\
400 \mathrm{mmHg} \\
\mathrm{PR}=4\end{array}$ & 230 & 1.3 & 1.6 \\
\hline $\begin{array}{l}200 \mathrm{~W} \\
400 \mathrm{mmHg} \\
\mathrm{PR}=3\end{array}$ & 150 & 0.9 & 1.4 \\
\hline
\end{tabular}

similar energy consumption results were reported by Liu et al. [2017] to dry asparagus cookies, and the lowest value was defined in pulse-spouted microwave vacuum drying. Additionally, microwave-vacuum drying time of the tomato was found to be approximately 4.8 times shorter than hot air drying as reported by Orikasa et al. [2018] because of the large power input of the devices used in that process.

\section{Scanning electron microscopy (SEM) analysis}

The effect of various drying conditions on the tissue structure of the dried "Deveci" pear slices was observed using scanning electron microscopy (Figure 5). The micrographs were examined by $1000 \times$ microscopy. The microwave-vacuum dried samples were demonstrated to be more regular in pore size and pore distribution in general. The cause may be rapid and extensive vaporization during microwave vacuum drying [Bai-Ngew et al., 2011]. Similarly, Jiang et al. [2014] provided better drying uniformity and production quality with pulsed microwave vacuum dried samples of banana. Again, the microwave-assisted vacuum-dried Litchis' structure was revealed to be clear and porous as shown by Song et al. [2015]

\section{CONCLUSIONS}

Quality analyses of "Deveci" pears regarding intermittent microwave-vacuum drying were performed. Overall, according to the experimental results, the " $200 \mathrm{~W}-400 \mathrm{mmHg}$ - $\mathrm{PR}=3$ " drying condition showed the lowest drying time, the lowest energy consumption, and a higher protein content. When comparing the mineral content, the $\mathrm{K}, \mathrm{Mg}, \mathrm{Fe}$, $\mathrm{Cu}$ and $\mathrm{Zn}$ levels were high at " $100 \mathrm{~W}-400 \mathrm{mmHg}-\mathrm{PR}=3$ ". Moreover, higher microwave power usage did not have a meaningful influence on the rehydration ratio. Total color difference $(\Delta E)$ ranged between 35.7 (" $200 \mathrm{~W}-200 \mathrm{mmHg}$ - PR=3") and 21.2 ("100 W - $400 \mathrm{mmHg}-\mathrm{PR}=3$ "). However, the structure of the dried samples was revealed to be clear and porous. Under these conditions, intermittent microwave-vacuum drying was proven to be an alternative for "Deveci" pear drying by some quality comparisons.
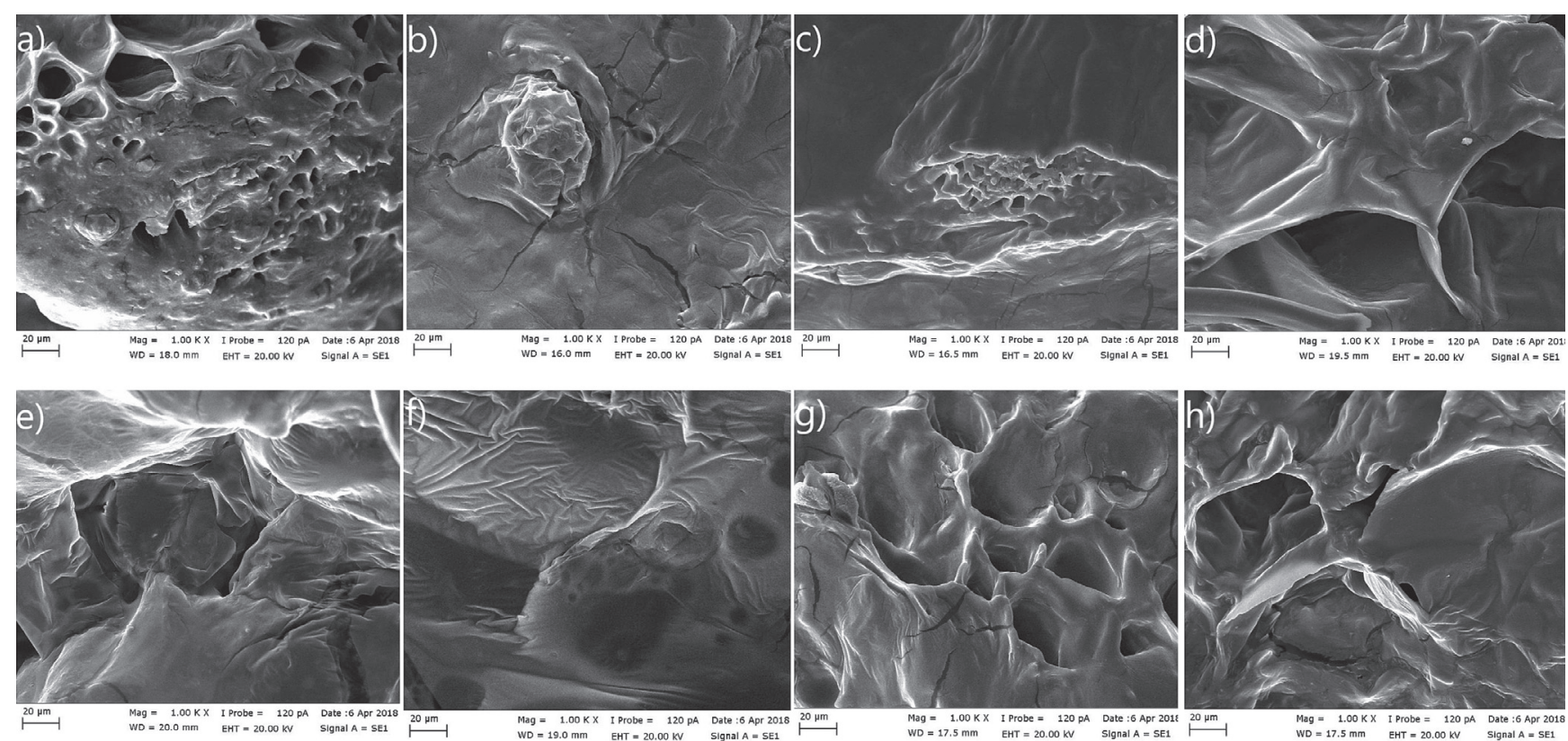

FIGURE 5. SEM images of dried pears: (a) $100 \mathrm{~W}-200 \mathrm{mmHg}-\mathrm{PR}=4$, (b) $100 \mathrm{~W}-200 \mathrm{mmHg}-\mathrm{PR}=3$, (c) $100 \mathrm{~W}-400 \mathrm{mmHg}-\mathrm{PR}=4$, (d) $100 \mathrm{~W}-400 \mathrm{mmHg}-\mathrm{PR}=3$, (e) $200 \mathrm{~W}-200 \mathrm{mmHg}-\mathrm{PR}=4$, (f) $200 \mathrm{~W}-200 \mathrm{mmHg}-\mathrm{PR}=3$, (g) $200 \mathrm{~W}-400 \mathrm{mmHg}-\mathrm{PR}=4$, and (h) $100 \mathrm{~W}-$ $400 \mathrm{mmHg}-\mathrm{PR}=3$. 


\section{RESEARCH FUNDING}

This research was financially supported by the Research Foundation of Uludag University (Project No. OUAP(Z)-2017/1).

\section{CONFLICT OF INTERESTS}

The authors report no declarations of interest.

\section{REFERENCES}

1. AlJuhaimi, F., Uslu, N., Özcan, M.M., ElBabiker, E.F., Ghafoor, K. (2016). Effect of drying on antioxidant activity, total phenol and mineral contents of pear fruits. Journal of Food Safety and Food Quality, 67, 164-167.

2. Amiripour, M., Habibi-Najafi, M.B., Mohebbi, M., Emadi, B. (2015). Optimization of osmo-vacuum drying of pear (Pyrus communis L.) using response surface methodology. Journal of Food Measurement and Characterization, 9(3), 269-280.

3. Antal, T., Tarek-Tilistyák, J., Cziáky, Z., Sinka, L. (2017). Comparison of drying and quality characteristics of pear (Pyrus communis L.) using mid-infrared-freeze drying and single stage of freeze drying. International Journal of Food Engineering, 13(4), 125-146.

4. AOAC (1960). Association of Official Analytical Chemists. Official Methods of Analysis (9th ed.). Washington, DC

5. Bai-Ngew, S., Therdthai, N., Dhamvithee, P. (2011). Characterization of microwave vacuum-dried durian chips. Journal of Food Engineering, 104(1), 114-122.

6. Bai-Ngew, S., Therdthai, N., Dhamvithee, P., Zhou, W. (2015). Effect of microwave vacuum drying and hot air drying on the physicochemical properties of durian flour. International Journal of Food Science \& Technology, 50(2), 305-312.

7. Celen, S., Kahveci, K. (2013). Microwave drying behaviour of tomato slices. Czech Journal of Food Science, 31 (2), 132-138.

8. Changrue, V., Orsat V., Raghavan, G.S.V. (2008). Osmotically dehydrated microwave-vacuum drying of strawberries. Journal of Food Processing and Preservation, 32 (5), 798-816.

9. Cheenkachorn, K., Jintanatham P., Rattanaprapa, S. (2012). Drying of papaya (Carica papaya L.) using a microwave-vacuum dryer. World Academy of Science, Engineering and Technology, 6, 899-903.

10. Clary, C.D., Mejia-Meza, E., Wang, S., Petrucci, V.E. (2007). Improving grape quality using microwave vacuum drying associated with temperature control. Journal of Food Science, 72(1), E23-E28.

11. Cui, Z.W., Xu, S.Y., Sun, D.W. (2003). Dehydration of garlic slices by combined microwave-vacuum and air drying. Drying Technology, 21(7), 1173-1184.

12. Dermelj, M., Bogenrieder, C., Hídvégi, M., Lásztity, R. (1995). Effect of microwave vacuum drying on protein and chlorophyll contents of blind nettle (Urtica urens L.). Periodica Polytechnica Chemical Engineering, 39, 77-84.

13. Dotto, G.L., Souza, T.B., Simões, M.R., Morejon, C.F., Moreira, M.F.P. (2017). Diffusive-convective model considering the shrinkage applied for drying of pears (pyrus spp.). Journal of Food Process Engineering, 40(4), 1-8, art. no. UNSP e12503.

14. Doymaz, İ. (2013). Experimental study on drying of pear slices in a convective dryer. International Journal of Food Science \& Technology, 48(9), 1909-1915.
15. Doymaz, İ., İsmail, O. (2012). Experimental characterization and modelling of drying of pear slices. Food Science and Biotechnology, 21(5), 1377-1381.

16. Dujmić, F., Brnčić, M., Karlović, S., Bosiljkov, T., Ježek, D., Tripalo, B., Mofardin, I. (2013). Ultrasound-assisted infrared drying of pear slices: textural issues. Journal of Food Process Engineering, 36(3), 397-406.

17. FAO (2018). Food and Agricultural Organization statistical database. http://faostat3.fao.org/download/Q/QC/E

18. Ferreira, D., Da Silva, J.A.L., Pinto, G., Santos, C., Delgadillo, I., Coimbra, M.A. (2008). Effect of sun-drying on microstructure and texture of S. Bartolomeu pears (Pyrus communis L.). European Food Research and Technology, 226(6), 1545-1552.

19. González-Martínez, C., Cháfer, M., Xue, K., Chiralt, A. (2006). Effect of the osmotic pre-treatment on the convective air drying kinetics of pear var. Blanquilla. International Journal of Food Properties, 9(3), 541-549.

20. Guiné, R.P.F., Barroca, M.J., Silva, V. (2013). Mass transfer properties of pears for different drying methods. International Journal of Food Properties, 16(2), 251-262. doi:

21. Guiné, R.P.F., Ferreira, D.M.S., Barroca, M.J., Gonçalves, F.M. (2007). Study of the drying kinetics of solar-dried pears. Biosystems Engineering, 98(4), 422-429.

22. Gunasekaran, S., Yang, H.W. (2007). Effect of experimental parameters on temperature distribution during continuous and pulsed microwave heating. Journal of Food Engineering, 78(4), 1452-1456. doi:

23. Han, Q.H., Yin, L.J., Li, S.J., Yang, B.N., Ma, J.W. (2010). Optimization of process parameters for microwave vacuum drying of apple slices using response surface method. Drying Technology, 28(4), 523-532.

24. Huang, L.L., Qiao, F., Fang, C.F. (2015). Studies on the microstructure and quality of iron yam slices during combined freeze drying and microwave vacuum drying. Journal of Food Processing and Preservation, 39(6), 2152-2160.

25. İzli, G. (2017). Total phenolics, antioxidant capacity, colour and drying characteristics of date fruit dried with different methods. Food Science and Technology (Campinas), 37(1), 139-147.

26. Jiang, H., Zhang, M., Mujumdar, A.S., Lim, R.X. (2014). Comparison of drying characteristic and uniformity of banana cubes dried by pulse-spouted microwave vacuum drying, freeze drying and microwave freeze drying. Journal of the Science of Food and Agriculture, 94(9), 1827-1834.

27. Kumar, V., Shrivastava, S.L. (2017). Optimization of vacuum-assisted microwave drying parameters of green bell pepper using response surface methodology. Journal of Food Measurement and Characterization, 11(4), 1761-1772.

28. Kuş, S. (2016). Mikrodalga enerjisiyle ayva ve armut meyvesinin kuruma davranışı ve modellemesi. MSc Thesis, Namık Kemal University, Tekirdağ, pp. 1-70, [https://tez.yok.gov.tr/UlusalTezMerkezi/tezSorguSonucYeni.jsp], Available: 08.10. 2018.

29. Liu, Z., Zhang, M., Fang, Z., Bhandari, B., Yang, Z. (2017). Dehydration of asparagus cookies by combined vacuum infrared radiation and pulse-spouted microwave vacuum drying. Drying Technology, 35(11), 1291-1301.

30. Lüle, F., Koyuncu, T. (2015). Convective and microwave drying characteristics of sorbus fruits (Sorbus domestica L.). ProcediaSocial and Behavioral Sciences, 195(3), 2634-2643. 
31. Lutovska, M., Mitrevski, V., Pavkov, I., Mijakovski, V., Radojčin, M. (2016). Mathematical modelling of thin layer drying of pear. Chemical Industry and Chemical Engineering, 22 (2), 191-199.

32. Orikasa, T., Koide, S., Sugawara, H., Yoshida, M., Kato, K., Matsushima, U., Tagawa, A. (2018). Applicability of vacuum-microwave drying for tomato fruit based on evaluations of energy cost, color, functional components, and sensory qualities. Journal of Food Processing and Preservation, 42 (6), 1-12.

33. Ozturk, A., Ozturk, B. (2014). The rootstock influences growth and development of 'Deveci' pear. Turkish Journal of Agricultural and Natural Sciences, 6, 1049-1053.

34. Ozturk, I., Ercisli, S., Kalkan, F., Demir, B. (2009). Some chemi$\mathrm{cal}$ and physico-mechanical properties of pear cultivars. African Journal of Biotechnology, 8(4), 687-693.

35. Santos, S.C., Guiné, R.P., Barros, A. (2014). Effect of drying temperatures on the phenolic composition and antioxidant activity of pears of rocha variety (Pyrus communis L.). Journal of Food Measurement and Characterization, 8(20, 105-112.

36. Silva, V., Figueiredo, A.R., Costa, J.J., Guiné, R.P.F. (2014). Experimental and mathematical study of the discontinuous drying kinetics of pears. Journal of Food Engineering, 134, 30-36.

37. Song, C.F., Cui, Z., Jin, G.Y., Mujumdar, A.S., Yu, J.F. (2015). Effects of four different drying methods on the quality characteristics of peeled litchis (Litchi chinensis Sonn.). Drying Technology, 33(5), 583-590.
38. Therdthai, N., Zhou, W. (2009). Characterization of microwave vacuum drying and hot air drying of mint leaves (Mentha cordifolia Opiz ex Fresen). Journal of Food Engineering, 91 (3), 482-489.

39. Tian, Y., Wu, S., Zhao, Y., Zhang, Q., Huang, J., Zheng, B. (2015). Drying characteristics and processing parameters for microwave-vacuum drying of kiwifruit (Actinidia deliciosa) slices. Journal of Food Processing and Preservation, 39(6), 2620-2629.

40. Ulubaş Serçe, Ç., Gazel, M., Çağlayan, K., Özgen, M. (2010). Effect of Candidatus phytoplasma pyri infection on fruit quality, total phenolic content and antioxidant capacity of 'Deveci' pear. Julius-Kühn-Archiv, 427, 407-411.

41. Zaki, N.A.M., Muhamad, I.I., Salleh, L.M. (2007). Drying characteristics of papaya (Carica papaya L.) during microwave-vacuum treatment. International Journal of Engineering and Technology, $4(1), 15-21$.

42. Zhang, Z., Wei, Q., Liu, C., Li, D., Liu, C., Jiang, N. (2017). Comparison of four pretreatments on the drying behavior and quality of taro (Colocasia esculenta L. Schott) slices during intermittent microwave vacuum-assisted drying. Drying Technology, 35(11), SI, 1347-1357.

43. Zielinska, M., Sadowski, P., Błaszczak, W. (2016). Combined hot air convective drying and microwave-vacuum drying of blueberries (Vaccinium corymbosum L.): drying kinetics and quality characteristics. Drying Technology, 34(6), 665-684.

Submitted: 23 July 2018. Revised: 9 October, 3 November, and 13 December 2018. Accepted: 18 December 2018. Published online: 07 February 2019. 